Article

\title{
Voting and Values: Grassroots Elections in Rural and Urban China
}

\author{
John James Kennedy ${ }^{1, *}$, Hongyan Liu ${ }^{2}$ and Haruka Nagao ${ }^{1}$ \\ ${ }^{1}$ Department of Political Science, University of Kansas, Lawrence, KS 66045, USA; E-Mails: kennedy1@ku.edu (J.J.K.), \\ haruka.nagao@ku.edu (H.N.) \\ ${ }^{2}$ School of Economics, Northwest University of Political Science and Law, 558 Xi'an, China; E-Mail: Ihy871211@126.com \\ * Corresponding author
}

Submitted: 29 December 2017 | Accepted: 26 January 2018 | Published: 22 June 2018

\begin{abstract}
Authoritarian leaders often claim that they promote democratic institutions such as elections and democratic values. In China, the central propaganda often promotes the right and duty of citizens to vote in local elections as well as the importance of citizens' input into the policy making process. However, there is often a gap between government rhetoric and reality. In this article, we use the China General Social Survey (CGSS) 2013 to evaluate the determinants of voting in local elections and democratic values (attitudes) in rural and urban China. The results show that respondents with higher education tend to have lower levels of democratic values and participate less in local elections, but respondents with only compulsory education are more likely to display democratic orientations and vote. This suggests the relative success as well as the limits of authoritarian democratic propaganda.
\end{abstract}

\section{Keywords}

China; democratic values; education; grassroots elections; voting

Issue

This article is part of the issue "Authoritarianism in the 21st Century", edited by Natasha Ezrow (University of Essex, UK).

(C) 2018 by the authors; licensee Cogitatio (Lisbon, Portugal). This article is licensed under a Creative Commons Attribution 4.0 International License (CC BY).

\section{Introduction}

In 2012, during the $18^{\text {th }}$ Party Congress, the Chinese Communist Party (CCP) announced the "12 Core Socialist Values", and "democracy" was near the top of the list behind "prosperity". The list also includes "freedom", "equality" and "justice". Interestingly, these are also some of the key terms used to describe democratic values in other countries in North America and Western Europe. In addition, the CCP also promotes elections especially voting for grassroots leaders in rural and urban China. However, the CCP defines democratic values, such as public participation in government and voting, as a duty rather than a right. Thus, the term "democracy" may have a different meaning for citizens in China than in the western democracies.

In general, much of the previous literature suggests that democratic values, such as the importance of voting and having a voice in the policy making process, tend to develop among the more educated urban middle class (Boix \& Stokes, 2003; Lipset, 1959; Moore, 1966). However, national surveys for the last two decades show that over $70 \%$ of respondents (rural and urban) support the central leadership (Dickson, 2016). Despite rapid urbanization and increased levels of education, general support among the middle class for the CCP and the single party regime remain relatively strong (Chen, 2013; Chen \& Dickson, 2008; Chen \& Lu, 2011; Tsai, 2007). At the same time, rural and urban residents are voting in competitive grassroots elections (Li, 2003; O'Brien \& Li, 2000; Tang, 2016). Thus, do more educated middle class urban residents hold stronger democratic values? What is the relationship between democratic values and voting in China?

One interesting puzzle is that even though there is wide spread support for the authoritarian regime most citizens tend to vote in grassroots elections and display a relatively high level of democratic values. Indeed, previ- 
ous studies and surveys show that most Chinese respondents agree that political participation and individuals having a voice in the policy making process is an important part of the democratic process (Chen \& Zhong, 2002; Shi, 1999). One critical debate is how these democratic values influence voting within an authoritarian regime. For example, Shi (1999) suggests that having democratic values promotes political efficacy and increases the likelihood of voting in grassroots elections because they believe even limited democratic institutions can replace corrupt local officials. However, Chen and Zhong (2002) argue that within an authoritarian regime people with more democratic orientations believe local elections are ineffective in replacing corrupt cadres and decide to abstain as a form of protest. Yet, both Shi (1999) and Chen and Zhong (2002) imply causality regarding the influence of democratic values on voting. Indeed, while there seems to be a correlation between voting and democratic values, the direction of causality is unclear. More importantly, they presuppose a positive relationship between education and democratic values. However, previous studies on China's grassroots elections have yet to disentangle the effect of education on democratic values and voting respectively. Moreover, there needs to be greater emphasis on the definition of democracy in the Chinese context.

In this article, we examine the possible relationship between voting in grassroots elections, democratic orientations, and education within an authoritarian regime. Previous studies examine democratic orientation and how this may influence voting either by promoting participation or abstention. In these studies, voting is the dependent variable and democratic values are the key independent variables. However, we argue that it is also important to look at how voting and education can influence democratic orientation. Using the 2013 China General Social Survey (CGSS), we find that education has strong influence on both voting behavior and democratic values. Moreover, it is not just the level of education, but the type of education (compulsory versus secondary) that affect voting and values. The results show that respondents with no education and those with college degrees tend to have the lowest voter turnout rates, suggesting a curvilinear relationship between voting and education. Yet, college educated respondents display the lowest proportion of democratic values. Thus, higher education is associated with lower voter participation as well as lower democratic orientations for both rural and urban residents. One implication is that respondents with compulsory education ( $9^{\text {th }}$ grade) or below are more likely to absorb state messaging regarding their duty to vote and accept the CCP definitions of democracy. On the other hand, higher educated respondents have a more diluted view of their civic duty to vote and are less acceptant of the CCP presentation of democratic duties (values).

This article is divided into four sections. For the first part, we examine the general literature on grassroots governing bodies in China as well as the relationship between voting, democratic values, and education. We also examine one of the key debates regarding the relationship between democratic values and voting behavior. The second section covers the theoretical assumptions and three key hypotheses. The first hypothesis examines voting as the dependent variable and democratic values and education as the main independent variables. The second hypothesis analyzes democratic values as the dependent variable, with voting and education as the main independent variables. The third hypothesis includes CCP membership as the independent variable and voting as the dependent variable in order to isolate the effect of education on voting. The third section is the descriptive and statistical analysis. We present two sets of regression models: one with voting as the dependent variable and the other with democratic orientation as the dependent variable. We find the level of education is a key explanatory factor regarding a respondent's willingness to perform their democratic duty (voting) and acceptance of the CCP democratic values. The fourth and final section is the concluding comments.

\section{Literature Review}

Democratic values under the CCP definition reflects citizens' collective duty to vote, as opposed to the western definition of liberal democracy that emphasizes individual rights and freedom. As Shi (1999) argues that the CCP promotes the idea that voting is citizens' duty, democracy in China indicates "duty" rather than "rights". Tang (2016) also identifies the unique conception of democracy within China and the need to separate liberal democracy from Chinese definition of democracy. Indeed, Dickson (2016) demonstrates that both political leaders and ordinary citizens in China perceive democracy as citizens' contributions to the state through political participation rather than citizens' individual rights and freedom. Perry (2008) argues that the increase of protests in China is a sign of "rules consciousness" and not "rights consciousness" (p. 47) and states that "political rights in modern China were consistently regarded as bound up with a moral responsibility to the larger political community" (p. 46). Therefore, democratic values in the Chinese context reflects a sense of duty to participate (including voting), rather than pursuits of individual rights.

The CCP promotes this conception of democracy through propaganda posters and state media. Through media, the CCP fosters a sense of duty to vote in local elections and also advocates the importance of indirect elections at the municipal, provincial and central levels. Beijing's Election Committee posts posters across the city that encourage people to vote in district people's congress elections. The posters connect vote to democracy as well as party leadership and rule abiding behaviors. For instance, one poster says "Cherish democratic rights. Cast a sacred and solemn vote". Other posters include wordings such as "Exercise electoral rights in 
accordance with law" and "Uphold a party leadership. Uphold and carry forward democracy". While the partystate uses words such as rights and democracy, they effectively connect democratic rights to a sense of duty and support for the current party leadership. Furthermore, the word "democracy" frequently appears on state media's news articles. For instance, a search for a word "democracy" in Chinese (“民主”) on the People's Daily (“人民网") web page produces over 240,000 articles. Indeed, scholars argue that education and state media indoctrinate people with the CCP definition of democracy (Lu, Aldrich, \& Shi, 2014; Lu \& Shi, 2015).

Western notions of democratic values are strongly associated with voting and education. Scholars suggest higher levels of education are associated with democratic values and in turn these values promote political participation (Cho, 2015; Evans \& Rose, 2012; McAllister \& White, 2017). McAllister and White (2017) examine the World Values Survey (WVS) from 1990-2012 and find that education has the strongest influence on a support for democracy. In China, scholars find similar patterns regarding education and democratic values. For instance, Chen and Zhong (1998) use a 1995 urban Beijing survey and show that higher levels of education are positively associated with greater democratic values. Zhong (2005) conducted a 2000 survey in rural Jiangsu, an economically developed yet rural area, and finds that along with other factors a higher level of education positively influences democratic values. Similarly, Lu (2004) finds the same results using the 2001 WVS in China.

Rural and urban grassroots elections represent the CCP attempt to promote party-state vision of participation and democracy. In the countryside, the lowest level of administration is the town, and within each town there are a number of village committees VCs (rural grassroots units). VC members are responsible for key village resources, such as collective land, and they also have a level of autonomy from the town government regarding local governance and policy implementation (Benewick, Tong, \& Howell, 2004; Gui, Cheng, \& Ma, 2006; Kennedy, 2002). In urban areas, the lowest administrative level is the street office and under each street office are several resident committees (RCs). However, RCs tend to have less autonomy and manage fewer resources than their rural counterparts (Heberer, 2008; Huang, 2008; Read, 2000). As a result, several scholars suggest that voter turnout tends to be lower for RC elections than for VCs (Chen \& Yao, 2005; Gui et al., 2006).

Several factors may influence voting behavior in rural and urban grassroots elections. Older residents tend to vote more than younger professionals even in the urban grassroots elections (Xiong, 2008). While education seems to have a positive influence on voting in western democracies, several studies find that education is negatively correlated with voting in China. Zheng and Zhu (2013) use the CGSS for 2006 and they find the high school and college educated rural and urban respondents are less likely to vote. Read (2003) finds the rel- atively new class of urban homeowners are more likely to participate in local elections. These residents have a greater stake in the $\mathrm{RC}$ elections regarding the need for services such as trash collections and upkeep of public spaces.

Although voting in grassroots elections is common in China, it is unclear how democratic values influence voting behavior. The debate is whether democratic orientation promotes participation or abstention in grassroots elections. Shi (1999) suggests that citizens' democratic orientations have a positive influence on voting in China. In a 1991 nationwide survey, Shi (1999) examines citizens' voting behaviors in rural and urban grassroots elections as well as the elections for deputies to local people's congress at both township and county levels. The election quality for the grassroots and people's congress vary by level of competitiveness. A semi-competitive election has multiple candidates for each seat whereas non-competitive typically have one candidate for each available position. Shi (1999) demonstrates that more educated citizens with greater democratic orientations are more likely to participate in semi-competitive elections, but they tend to abstain from non-competitive elections. Furthermore, the perception that semi-competitive elections can replace corrupt local leaders increases internal efficacy and this is associated with a higher voter turnout. Therefore, Shi (1999) concludes that higher educated people hold democratic values and they vote in local elections to articulate their interests in replacing local officials and fostering democracy.

However, some scholars argue that educated citizens who hold democratic values within an authoritarian regime are more likely to abstain from voting. For example, Zhong and Chen (2002) conducted a survey in rural Jiangsu province in 2000, and find that people who have democratic orientations, internal efficacy, and a higher level of education are less likely to vote in the village committee elections. In addition, Zheng and Zhu (2013) use the 2006 CGSS to examine factors that influence voter behavior in rural and urban grassroots elections, and they find that democratic values have no significant influence on voting. Chen and Zhong (2002) evaluate a 1995 survey conducted in urban Beijing and illustrate that respondents with democratic orientations and internal efficacy are less likely to vote, whereas those who support the authoritarian regime are more likely to vote. These citizens abstain from voting, because the "constraints are incompatible with their democratic values" (Chen \& Zhong, 2002 , p. 185). Moreover, people who vote in these elections also display a level of compliance and support for the central leadership.

The notion that citizens who only complete compulsory education are more likely to support the authoritarian system and participate in grassroots elections is similar to previous studies that examine the relationship between education and regime support. Geddes and ZaIler (1989) as well as Key (1961) suggest that the educational experience, especially compulsory education, can 
have a direct influence on an individual's political opinion. However, citizens who complete higher education or college (post compulsory) learn to evaluate rather than simply absorb state information and they may even begin to resist state messages and propaganda. Thus, these educated individuals may also abstain from voting within the authoritarian system.

Yet these studies assume a positive relationship between levels of education and democratic values. The existing literature adopts the western notion of liberal democracy that focuses on individual rights and freedom. As a result, previous studies start with the assumption that education increases democratic values, and examine whether this orientation encourages people to vote or abstain. In this study, we start with the CCP definition of democracy and test the notion of duties rather than rights. As Key (1961) suggests, compulsory education and party-state propaganda may have a strong influence on citizens' perception of democratic values and strengthen their sense of duty. However, given the CCP definition of democratic values, it is more likely that higher educated citizens (post compulsory) and professionals tend to have a weaker sense of duty. These educated citizens may choose to not vote, and may display lower levels of commitment to their democratic duties (lower democratic values). Indeed, non-voting may not reflect stronger rights consciousness in a liberal democratic vein, but rather a form of noncompliance with their perceived duties.

\section{Hypothesis and Measures}

In order to test the difference between rights and duties, we evaluate three hypotheses. The first hypothesis examines an influence of democratic values on voting. Shi (1999) adopts the western definition of democratic values and argues that voters with democratic values are more likely to vote to replace local officials. However, we start with the CCP definition of "duty to vote" rather than the western definition of individual rights. Thus, when democratic values are defined as "duty to vote", respondents with higher levels of democratic values should be more likely to vote. Therefore, we test (H1) democratic values hypothesis: respondents with higher level of democratic values are more likely to vote in grassroots elections.

The second hypothesis investigates the impact of education on voting and democratic values respectively. The general assumption in the literature is that greater education is positively associated with voting (Boix \& Stokes, 2003; Lipset, 1959; Moore, 1966). Scholars also suggest that education is positively associated with the western notion of democratic values (Cho, 2015; Evans \& Rose, 2012; McAllister \& White, 2017). Overall education seems to be the driving force influencing democratic values (rights consciousness) and voting. Furthermore, the literature assumes a covariation of education and democratic values and examines their effect on voting (Chen
\& Zhong, 2002; Shi, 1999). However, with democracy defined as duty to vote, theoretically "democratic values and voting" should correspond, rather than "education and democratic values". In other words, we suggest education should have a similar effect on both democratic values and voting. Thus, we examine two dependent variables, democratic values and voting, and we test $(\mathrm{H} 2)$ education hypothesis: education influences democratic values and voting in the same direction.

The third hypothesis further assesses an influence of education on voting by considering CCP memberships. Other studies indicate that compulsory education will strengthen citizens' support for the state and conform to the political views of the regime (Geddes \& Zaller, 1989; Key, 1961). This also suggests that people who attain higher levels of education may challenge these positive perceptions of the state. However, starting with the CCP definition of democratic values as a civic duty, higher education should reduce the effect of indoctrination and propaganda as well as dilute their sense of duty. Thus, educated respondents are less likely to vote. Yet, even among educated, if respondents are CCP members, then they should have a much stronger sense of duty to participate in local elections. Thus, we test (H3) the CCP membership hypothesis: educated CCP members are more likely to vote than educated non-party members.

We use the 2013 CGSS to investigate the hypotheses. The CGSS is a collaborative survey with Renmin University of China, Department of Sociology, and the Survey Research Center of Hong Kong University of Science and Technology. Since 2003 the CGSS has conducted several nationwide surveys and the 2013 survey has a random sample of over 11,000 respondents. This sample size is much larger than that of the 2011 Asian Barometer Surveys in China $(N=3,473)$ and the 2012 WVS in China $(N=2,300)$. The large sample size is one of the key advantages of the survey because it reduces the standard error and enables more precise analysis. For example, education variable divides respondents according to five levels of educational attainment, and each of the five categories contain more than 1,000 observations. Finally, the 2013 CGSS contains a specific set of questions on democratic values. The survey questions directly inquire people's perceptions of democracy and offer a suitable operationalization of democratic values. Some previous studies tend to use "demand for democracy" as conceptualization of democratic values, but this assumes a liberal democracy definition (Chen \& Zhong, 2002; Shi, 1999). Instead, the CGSS's questions examine perceptions of democratic values such as voting and people's voice in government.

Table 1 of the Annex displays the key variable names and definitions as well as percentage and frequencies from the 2013 CGSS. The four key variables are voting, democratic values, levels of education, and CCP membership. Voting is reported participation in the last election. Although the survey age range is from 14 to 94 years old, we only include respondents over 
the age of 20 to ensure a sample of possible voters over the age of 18 for the last election (grassroots election occur every three years). Voting is dependent variable in the first set of regression models and independent variable in the second set of regression models. Democratic values is an index combining the following three survey questions on democratic values: (1) democracy means the government should be for the people (“民主就是政府要为民做主”), (2) a country is a democracy only when ordinary people have direct voices and decision power on important state and local matters (“只有老百姓对国家和地方的大事都有直接的发言权 或决定权，才算是民主”)，(3) a country is a democracy if ordinary people have rights to vote for their own representatives to discuss important state and local matters (“如果老百姓有权选举自己的代表去讨论国家和地方 的大事, 也算是民主”). The answers to each question are coded dichotomously as either "agree" or "disagree" and comprise the democratic values index that ranges from 3 to 6 ( 6 is the highest level of democratic values). Democratic values is independent variable in the first set of regression models and dependent variable in the second set of regression models.

Education is self-reported completion of specific grade levels. The key distinction is the difference between completion of compulsory education (middle school or 9 years) and post compulsory education (high school and college). The number of respondents with CCP membership accounts for $10 \%$ of the entire sample. This is slightly higher than the $6 \%$ national percentage of CCP members.

The control variables include generation, election quality, class status, home ownership status, and gender. To test generational influence, we divide the population into two groups: those born before and after 1968. This is a delineation based on respondents who came of age during the reform era (born after 1968) and those who came of age before. County level election quality is also a self-reported measure based on the individual question whether or not the respondent knows the election process. Only about $30 \%$ of the respondents could identify the type of election process. The elections vary from open nominations and competitive elections to no elections (i.e. appointed positions). For those who know the process, $58 \%$ reported an open election process. We then examine the number of respondents who reported open elections within the county, if at least half reported an open election then we code it as "open elections". We find a clear variation in election quality at the county level. Class status is a self-reported measure of class ranging from 1 (lowest) to 10 (highest). The largest proportion is the $5^{\text {th }}$ category or the middle class at $33 \%$. Both homeownerships and gender are measured dichotomously.

\section{Analysis}

The descriptive data suggests no clear relationship between voting and democratic values. Table 2 of the An- nex shows that only about $50 \%$ of respondents with the highest level of democratic orientations are likely to vote. While respondents who have democratic values are more likely to vote than those who do not, about half of the respondents who display democratic values did not vote at all. Thus, the data does not easily resolve the democratic orientation and voter abstention debate (Chen \& Zhong, 2002; Shi, 1999). Indeed, there can be a number of reasons for not voting, from apathy to busy schedules, as well as diminished sense of duty.

As Gui et al. (2006), Chen and Yao (2005), and Xiong (2008) point out, voter turnout is much lower in urban grassroots elections. There is a $14 \%$ difference in the likelihood to vote between rural and urban respondents. This is possibly due to the fact that urban RCs have fewer resources and decision-making power than elected VC members (Xiong, 2008).

Generational differences, election quality and homeownership have an influence on voting, while gender and class have little impact. The majority, just over $60 \%$, of younger respondents (under 45) did not vote, but the majority of the older respondents voted. This pattern holds for both rural and urban grassroots elections. Indeed, as Xiong (2008) suggests the vast majority (64\%) of the older urban respondents voted in the last election as opposed to $36 \%$ of the younger generation. Election quality can also influence voter behavior especially within an authoritarian regime. In fact, the majority of respondents (58\%) did not vote in the closed non-competitive elections, while close to $60 \%$ of the respondents that experienced an open election process participated in the election. The descriptive data also shows that homeownership has a positive influence on voting in local elections. As Read (2003) suggests, homeowners are more politically active than renters and tend to be involved in grassroots elections especially in the urban areas.

Gender and class status have little effect on voting behavior. The proportion of lower and higher classes are just as likely to vote (or not vote) as the middle class. Unlike the middle class expectations within the traditional modernization literature, such as Lipset (1959) and Moore (1966), voting behavior of middle class respondents are no different than other classes. Gender also has little influence on voting. However, females are slightly less likely to vote than male respondents.

One of the most striking determinates on voting is education. Table 3 of the Annex displays the non-linear pattern of influence. The smallest proportion of voters are among respondents with the lowest and highest levels of education. Indeed, only $33 \%$ of college educated respondents voted in the last election. However, majority of respondents, who attended or only completed compulsory education, voted in the last grassroots election. It is the middle educated rather than the middle class who have a higher proportion of political participation. This reflects Zheng and Zhu (2013) as well as Li's (2016) findings regarding the non-linear effect of education on voting. Table 4 of the Annex shows the similar non-linear 
relationship between education and voting among CCP members. However, compared to the entire sample, CCP members tend to have higher educational attainment. About $67 \%$ of the CCP members completed higher education while only $35 \%$ of the total sample completed higher education. Overall CCP members are far more likely to vote than non-party members.

The regression analysis suggests a similar pattern observed in the descriptive tables. Table 5 of the Annex displays four logit regression models with voting in the last election as dependent variable. This is dichotomous variable and we used a logit model. As the descriptive tables suggest, Model 1 shows the statistical significance of democratic values, elections quality, and generation as well as homeownership, and CCP membership. Gender and class have no influence on voting. The variable "rural" is 1 for rural and 0 for urban. As the descriptive statistics suggest, rural respondents are more likely to vote. Education is not statistically significant in Model 1, but when we add the squared education term (quadratic) in Model 2 to test for a non-linear influence we find that education has a curvilinear influence on voting.

Model 3 only examines rural respondents. Interestingly, the effect of democratic values is not as strong as urban respondents, but it is still positive and statistically significant. Thus, a sense of duty (state conception of democratic values) seems to have a positive association with voting. Education remains strong and statistically significant. Also, males are more likely to vote than females in rural grassroots elections.

Finally, Model 4 examines urban respondents. In this model, democratic values are more strongly correlated with voting than the rural model. Also, CCP membership is positive and statistically significant in all the four models. Thus, CCP members are much more likely to vote than non-party members. The data shows that higher educated respondents are less likely to vote, but CCP members tend to be higher educated. This suggests that the sense of duty is higher among party members than collage educated nonparty members.

The results support $\mathrm{H} 1$ that democratic values positively influence voting behaviors. The results are in line with the theoretical assumption that democratic values, defined as sense of duty, increases the likelihood of voting. The findings appear to support Shi's (1999) argument, yet under a different rationale. The non-linear effect of education remains a strong factor for all three models, but the magnitude (z-score) of education is lower for urban respondents. In order to test the influence of education on an individual's sense of duty, we need to examine democratic values as dependent variable.

Table 6 of the Annex displays the descriptive relationship between democratic orientation and education. First, the overall measure of democratic values is relatively high. For the whole sample, $65 \%$ of the respondents display the highest level of democratic values or a sense of duty to the state. However, with $65 \%$ as the base line, Table 6 shows a clear negative relationship between education and democratic values with college educated respondents $18 \%$ below the baseline and respondents with no education $13 \%$ above. This suggests that higher levels of education, especially college, erodes democratic orientation. However, given the definition, it is more accurate to describe this result as an erosion of the respondent's perceived duty to participate in state functions such as voting.

Table 7 of the Annex shows the ordered logit regression models with democratic values as the dependent variable. Like the regression in Table 5 , voting is positively associated with democratic values. However, in this case, correlation is not causation. Both voting and democratic values are viewed as a sense of duty and this varies with the level of education. Model 2 in Table 7 suggests older rural respondents are more likely to hold democratic orientation. This is also associated with education. Older respondents tend to have lower levels of education especially in the countryside. Thus, we expect them to display a high level of duty to the state.

The results support $\mathrm{H} 2$ that education influences democratic values and voting in the same direction. Table 7 shows that respondents with the lower levels of education are more likely to display a sense of duty to vote and participate in the political system. The results from the two regression models in Table 5 and Table 7 suggest that education drives both voting and measures of democratic orientation into the same direction. Our results differ from previous research because we start with a CCP definition of democratic values.

The results from Table 4, Table 5 and Table 7 support H3 that educated CCP members are more likely to vote than educated non-party members. Table 4 shows that CCP members are mostly higher educated, and Table 4 and Table 5 show that they are more likely to vote. Table 7 shows that CCP membership and democratic values have a negative relationship, but not statistically significant. This indicates that CCP members are more likely to fulfil their duty to vote even though they are higher educated.

The reason why higher educated respondents are less likely to vote and have a reduced sense of duty is due to the education system and indoctrination of the CCP definition of democracy, especially through compulsory education. The CCP has historically claimed to be democratic and promotes the CCP definition of democracy and political participation including the right to vote and the role of the people in decision making. Moreover, the most intensive exposure to government perspective is compulsory education. Observing American public opinion, V. O. Key (1961) argued that "formal education may serve to indoctrinate people into the more-or-less official political values of the culture" (p. 340). The effectiveness of this indoctrination may be greater in authoritarian regimes (Geddes \& Zaller, 1989; Kennedy, 2009). Indeed, compulsory education in China instils the ideals of a socialist democracy that includes the right to vote and people's influence in the decision-making process, which 
indoctrinates people to perceive a sense of duty to vote as democratic values.

Higher education is typically viewed as the opportunity to expand the educational experience and question the status quo. This is at the heart of the liberal democratic ideal of higher education and enlighten political views especially questioning authority. However, higher education in China does not provide this type of liberal experience, but the high school and college educational opportunities do move beyond the compulsory education particularly in the areas of career choice and specialization. Post compulsory education may have the unintended consequence of diluting the sense of political or civic duty that was instilled during elementary and middle school years. The only way to maintain the CCP democratic duty after college is to be involved in a career choice that includes CCP membership. In fact, many younger CCP members join when they were in college in order to improve their employment chances.

\section{Conclusion}

One of the most challenging aspects of studying authoritarian regimes, especially in China, is the problem of translation and definitions. The word democracy in China is minzhu and it literally translates to "People in Charge". The "people" are the face of the authoritarian leadership from the inception of the People's Republic of China to the " 12 Core Socialist Values" of the 18th Party Congress. While the central leadership introduced village elections and political reforms in the 1980s and 1990s, the intention was not to democratize China from a liberal democracy perspective, but to expand the democratic duties of the "people". Most Chinese grow up hearing the words "democracy", "freedom" and "elections", but these terms do not reflect the individual rights as they are understood in liberal democracies. Instead, the terms are part of the party state lexicon including conception of the "people" and duties as well as service to the state.

When evaluating Chinese attitudes or perceptions of democracy, researchers need to discuss not only the accepted social and political definitions, but also how and where citizens can be exposed to alternative definitions. Our study started off with the CCP definition of democracy and the concept of duty rather than rights. Given this definition, the results seem to contradict previous assumptions regarding the relationship between democratic values, voting and education. While our study does not support the ideal that higher education instills liberal values even in China, a closer look suggests that our results do support the general idea that higher education can dilute state propaganda and indoctrination in compulsory education. This may have great implications for regime support in the future.

The remaining puzzle is that while most surveys still display relatively strong public support for the central leadership, a growing number of citizens are completing high school and college education especially in urban ar- eas. In addition, China is urbanizing at a rapid pace. In order to maintain public support, the CCP aggressively promoted the " 12 Core Socialist Values" during the $18^{\text {th }}$ (2012) and $19^{\text {th }}$ (2017) Party Congress. Thus, is the Core Socialist Values campaign generating greater trust and support for the regime or widening the gap between government rhetoric and practice?

\section{Acknowledgments}

We are grateful to Shi Yaojiang, the director of the Northwest Socioeconomic Development Research Center (NSDRC) at Shaanxi Normal University, China, and the three reviewers for their very insightful suggestions regarding earlier drafts of the article. This research was supported by the "111 Project", grant number B16031.

\section{Conflict of Interests}

The authors declare no conflict of interests.

\section{References}

Benewick, R., Tong, I., \& Howell, J. (2004). Self-governance and community: A preliminary comparison between villagers' committees and urban community councils. China Information, 18(1), 11-28.

Boix, C., \& Stokes, S. C. (2003). Endogenous democratization. World Politics, 55(4), 517-549.

Chen, J. (2013). A middle class without democracy: Economic growth and the prospects for democratization in China. Oxford: Oxford University Press.

Chen, J., \& Dickson, B. J. (2008). Allies of the state: Democratic support and regime support among China's private entrepreneurs. The China Quarterly, 196, 780-804.

Chen, J., \& Lu, C. (2011). Democratization and the middle class in China: The middle class's attitudes toward democracy. Political Research Quarterly, 64(3), 705-719.

Chen, W. D., \& Yao, L. (2005). Xuanju xingwei beihou: Touji boyi [Behind the election: Speculation game]. Huazhong Normal University Journal (Humanities and Social Sciences Edition), 44(3), 61-66.

Chen, J., \& Zhong, Y. (1998). Defining the political system of post-Deng China: Emerging public support for a democratic political system. Problems of PostCommunism, 45(1), 30-42.

Chen, J., \& Zhong, Y. (2002). Why do people vote in semicompetitive elections in China? The Journal of Politics, 64(1), 178-197.

Cho, Y. (2015). How well are global citizenries informed about democracy? Ascertaining the breadth and distribution of their democratic enlightenment and its sources. Political Studies, 63(1), 240-258.

Dickson, B. (2016). The dictator's dilemma: The Chinese Communist Party's strategy for survival. Oxford: Oxford University Press. 
Evans, G., \& Rose, P. (2012). Understanding education's influence on support for democracy in subSaharan Africa. Journal of Development Studies, 48(4), 498-515.

Geddes, B., \& Zaller, J. (1989). Sources of popular support for authoritarian regimes. American Journal of Political Science, 33(2), 319-347.

Gui, Y., Cheng, J. Y., \& Ma, W. (2006). Cultivation of grassroots democracy: A study of direct elections of residents committees in Shanghai. China Information, 20(1), 7-31.

Heberer, T. (2008). Institutional change and legitimacy via urban elections? People's awareness of elections and participation in urban neighborhoods (Shequ). In T. Heberer \& G. Schubert (Eds.), Regime legitimacy in contemporary China: Institutional change and stability (pp. 79-105). London: Routledge.

Huang, W. P. (2008). Zhongguo xuanju minzhu: Cong guangdu dao shendu. [The breadth and depth of China's electoral democracy]. Jilin daxue shehuikexue xuebao (Jilin University Social Science Journal), 48(3), 29-35.

Kennedy, J. J. (2002). The face of "grassroots democracy" in rural China: Real versus cosmetic elections. Asian Survey, 42(3), 456-482.

Kennedy, J. J. (2009). Maintaining popular support for the Chinese Communist Party: The influence of education and the state-controlled media. Political Studies, 57(3), 517-536.

Key, V. O. (1961). Public opinion and American democracy. New York, NY: Knopf.

Li, L. (2003). The empowering effect of village elections in China. Asian Survey, 43(4), 648-662.

Li, K. Q. (2016). Zhongguo jiceng xuanju zhong toupiao hang wei chayi yanjiu [Research on voting behavior in Chinese grassroots elections]. Shenyang gongye daxue xuebao (shehui kexue ban) Journal of Shenyang University of Technology (Social Sciences Edition), 9(4), 356-361.

Lipset, S. M. (1959). Some social requisites of democracy: Economic development and political legitimacy. American Political Science Review, 53(1), 69-105.

Lu, C. L. (2004). Democratic values among Chinese people: Analysis of a public opinion survey. China Perspectives, $55,40-48$.

Lu, J., Aldrich, J., \& Shi, T. (2014). Revisiting media effects in authoritarian societies: Democratic conceptions, collectivistic norms, and media access in urban
China. Politics \& Society, 42(2), 253-283.

Lu, J., \& Shi, T. (2015). The battle of ideas and discourses before democratic transition: Different democratic conceptions in authoritarian China. International Political Science Review, 36(1), 20-41.

McAllister, I., \& White, S. (2017). Economic change and public support for democracy in China and Russia. Europe-Asia Studies, 69(1), 76-91.

Moore, B. (1966). Social origins of democracy and dictatorship. Boston, MA: Beacon Press.

O’Brien, K. J., \& Li, L. (2000). Accommodating “democracy" in a one-party state: Introducing village elections in China. The China Quarterly, 162, 465-489.

Perry, E. J. (2008). Chinese conceptions of "rights": From Mencius to Mao and now. Perspectives on Politics, 6(1), 37-50.

Read, B. L. (2000). Revitalizing the state's urban "nerve tips". The China Quarterly, 163, 806-820.

Read, B. L. (2003). Democratizing the neighbourhood? New private housing and home-owner self-organization in urban China. The China Journal, 49, 31-59.

Shi, T. (1999). Voting and nonvoting in China: Voting behavior in plebiscitary and limited-choice elections. The Journal of Politics, 61(4), 1115-1139.

Tang, W. (2016). Populist authoritarianism: Chinese political culture and regime sustainability. New York, NY: Oxford University Press.

Tsai, K. S. (2007). Capitalism without democracy: The private sector in contemporary China. Ithaca, NY: Cornell University Press.

Xiong, Y. H. (2008). Shequ xuanju: Zai zhengzhi lengmo yu gao toupiao lu zhi jian [Community election: Between political indifference and high turnout]. Shehui (Society), 28, 180-204.

Zheng, L., \& Zhu, Z. Y. (2013). Jiaoyu shifou cujinle zhongguo gongmin de zhengzhi xuanju toupiao canyu [Whether education has promoted the participation of Chinese citizens in their political elections]. Beijing daxue jiaoyu pinglun (Peking University Education Review), 11(2), 165-192.

Zhong, Y. (2005). Democratic values among Chinese peasantry: An empirical study. China: An International Journal, 3(2), 189-211.

Zhong, Y., \& Chen, J. (2002). To vote or not to vote: An analysis of peasants' participation in Chinese village elections. Comparative Political Studies, 35(6), 686-712.

\section{About the Authors}

John James Kennedy is an associate professor at the University of Kansas and he is also chair of the executive board for the Northwest Socioeconomic Development Research Center (NSDRC) and a distinguished overseas professor (haiwai mingshi) at Shaanxi Normal University, Xian China.

Hongyan Liu is an assistant professor at the Northwest University of Politics \& Law, Xian China, and an associate researcher at Northwest Socioeconomic Development Research Center (NSDRC) and the Center for Experimental Economics in Education (CEEE) at Shaanxi Normal University. 
Haruka Nagao is a doctoral student at the University of Kansas and she is a research affiliate at the Northwest Socioeconomic Development Research Center (NSDRC) at Shaanxi Normal University. 
Annex

Table 1. Descriptive data for voting and democratic values. Source: China General Social Survey 2013.

\begin{tabular}{|c|c|c|c|}
\hline Code & Variable Label & Percentage & Frequency \\
\hline \multirow[t]{3}{*}{ vote } & Voted in last VC and RC elections (over 20) & & \\
\hline & Yes [1] & $48 \%$ & 4,922 \\
\hline & No [0] & $52 \%$ & 5,389 \\
\hline \multirow[t]{5}{*}{ demo123 } & Democratic Values Index & & \\
\hline & Agree to all three [6] & $65 \%$ & 5,947 \\
\hline & Agree to two out of three [5] & $25 \%$ & 2,340 \\
\hline & Disagree to two out of three [4] & $9 \%$ & 817 \\
\hline & Disagree to all three [3] & $1 \%$ & 114 \\
\hline \multirow[t]{3}{*}{ generation } & Respondents born before and after 1968 & & \\
\hline & Over 45 [1] & $49 \%$ & 5,650 \\
\hline & Under $45[0]$ & $51 \%$ & 5,788 \\
\hline \multirow[t]{6}{*}{ edu } & Level of Education & & \\
\hline & No Education [1] & $13 \%$ & 1,484 \\
\hline & Elementary School [2] & $23 \%$ & 2,582 \\
\hline & Middle School [3] & $29 \%$ & 3,326 \\
\hline & High School [4] & $19 \%$ & 2,180 \\
\hline & College [5] & $16 \%$ & 1,863 \\
\hline \multirow[t]{3}{*}{ coelect } & $\begin{array}{l}\text { Quality of election grassroots election: good quality is open nomination } \\
\text { process and competitive election within the county }\end{array}$ & & \\
\hline & Open Elections, Yes [1] & $37 \%$ & 4,099 \\
\hline & No [0] & $63 \%$ & 7,123 \\
\hline \multirow[t]{3}{*}{ rural } & Hukou status at the time of the survey & & \\
\hline & Rural [1] & $55 \%$ & 6,333 \\
\hline & Urban[0] & $45 \%$ & 5,083 \\
\hline \multirow[t]{3}{*}{ ownhome } & Respondent owns home & & \\
\hline & Yes [1] & $50 \%$ & 5,672 \\
\hline & No $[0]$ & $50 \%$ & 5,731 \\
\hline \multirow[t]{11}{*}{ class } & Self-identified class status: Highest 10, Lowest 1 & & \\
\hline & 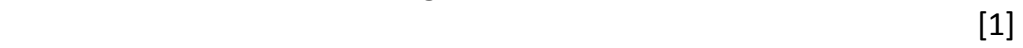 & $7 \%$ & 788 \\
\hline & [2] & $8 \%$ & 867 \\
\hline & [3] & $16 \%$ & 1,778 \\
\hline & [4] & $18 \%$ & 2,074 \\
\hline & [5] & $33 \%$ & 3,708 \\
\hline & [6] & $12 \%$ & 1,319 \\
\hline & [7] & $5 \%$ & 518 \\
\hline & [8] & $2 \%$ & 234 \\
\hline & [9] & 0 & 35 \\
\hline & [10] & $1 \%$ & 74 \\
\hline \multirow[t]{2}{*}{ gender } & Male [1] & $50 \%$ & 5,756 \\
\hline & Female [0] & $50 \%$ & 5,682 \\
\hline \multirow[t]{3}{*}{ party } & Chinese Communist Party member & & \\
\hline & Yes [1] & $10 \%$ & 1,161 \\
\hline & No [0] & $90 \%$ & 10,277 \\
\hline
\end{tabular}


COGITATIO

Table 2. Voting and democratic values for respondent over 20 years old. Source: China General Social Survey 2013.

\begin{tabular}{lcccc}
\hline \multicolumn{4}{c}{ Democratic Values } & \\
\hline Voting & Low & Medium Low & Medium High & High \\
\hline No & $74 \%$ & $65 \%$ & $55 \%$ & $49 \%$ \\
Yes & $26 \%$ & $35 \%$ & $45 \%$ & $51 \%$ \\
\hline Total & $100 \%$ & $100 \%$ & $100 \%$ & $100 \%$ \\
(freq) & $(91)$ & $(688)$ & $(2,042)$ & $(5,484)$ \\
\hline
\end{tabular}

Table 3. Voting and the level of education for respondents over 20 years old. Source: China General Social Survey 2013.

\begin{tabular}{lccccc}
\hline & & & & \\
\hline Voting & No Education & Elementary & Middle & High & \\
\hline No & $55 \%$ & $43 \%$ & $49 \%$ & $56 \%$ & College \\
Yes & $45 \%$ & $57 \%$ & $51 \%$ & $44 \%$ & $67 \%$ \\
\hline Total & $100 \%$ & $100 \%$ & $100 \%$ & $100 \%$ & $33 \%$ \\
(freq) & $(1,425)$ & $(2,481)$ & $(3,070)$ & $(1,833)$ & $(1,500)$ \\
\hline
\end{tabular}

Table 4. Voting and the level of education for respondents over 20 years old with CCP memberships. Source: China General Social Survey 2013.

\begin{tabular}{lcccrr}
\hline & & & & & \\
\hline Voting & No Education & Elementary & Middle & High & College \\
\hline No & $37 \%$ & $31 \%$ & $34 \%$ & $38 \%$ & $57 \%$ \\
Yes & $63 \%$ & $69 \%$ & $66 \%$ & $62 \%$ & $43 \%$ \\
\hline Total & $100 \%$ & $100 \%$ & $100 \%$ & $100 \%$ & $100 \%$ \\
(freq) & $(41)$ & $(108)$ & $(218)$ & $(260)$ & $(469)$ \\
\hline
\end{tabular}


Table 5. Factors that influence voting in village committee (rural) and residence committee (urban) elections in China (2013) for respondents over 20 years old.

\begin{tabular}{|c|c|c|c|c|}
\hline \multirow[b]{2}{*}{ Variables } & \multicolumn{4}{|c|}{ Coefficient (z-score) } \\
\hline & Model 1 & Model 2 & $\begin{array}{c}\text { Model } 3 \\
\text { (Rural) }\end{array}$ & $\begin{array}{c}\text { Model } 4 \\
\text { (Urban) }\end{array}$ \\
\hline Democratic Value & $\begin{array}{l}0.20 * * * \\
(5.58)\end{array}$ & $\begin{array}{l}0.19 * * * \\
(5.22)\end{array}$ & $\begin{array}{c}0.13 * \\
(2.33)\end{array}$ & $\begin{array}{l}0.24 * * * \\
(4.97)\end{array}$ \\
\hline Election Quality & $\begin{array}{l}0.57 * * * \\
(11.12)\end{array}$ & $\begin{array}{l}0.58 * * * \\
(11.33)\end{array}$ & $\begin{array}{l}0.53 * * * \\
(7.60)\end{array}$ & $\begin{array}{l}0.57 * * * \\
(7.18)\end{array}$ \\
\hline Generation (age) & $\begin{array}{l}0.53 * * * \\
(10.11)\end{array}$ & $\begin{array}{l}0.54 * * * \\
(10.29)\end{array}$ & $\begin{array}{l}0.57 * * * \\
(8.00)\end{array}$ & $\begin{array}{l}0.59 * * * \\
(7.16)\end{array}$ \\
\hline Rural & $\begin{array}{l}0.67 * * * \\
(11.84)\end{array}$ & $\begin{array}{l}0.63 * * * \\
(10.95)\end{array}$ & & \\
\hline Gender & $\begin{array}{c}0.06 \\
(1.18)\end{array}$ & $\begin{array}{c}0.02 \\
(0.40)\end{array}$ & $\begin{array}{c}0.14 * \\
(2.06)\end{array}$ & $\begin{array}{r}-0.16 * \\
(2.21)\end{array}$ \\
\hline Education & $\begin{array}{c}-0.02 \\
(0.60)\end{array}$ & $\begin{array}{l}0.79 * * * \\
(8.24)\end{array}$ & $\begin{array}{l}1.05 * * * \\
(7.28)\end{array}$ & $\begin{array}{l}0.66 * * * \\
(3.75)\end{array}$ \\
\hline Education Squared & & $\begin{array}{l}-0.13 * * * \\
(8.69)\end{array}$ & $\begin{array}{l}-0.20 * * * \\
(7.31)\end{array}$ & $\begin{array}{l}-0.11 * * * \\
(4.10)\end{array}$ \\
\hline Class Status & $\begin{array}{c}0.002 \\
(0.11)\end{array}$ & $\begin{array}{c}0.004 \\
(0.24)\end{array}$ & $\begin{array}{c}-0.002 \\
(0.12)\end{array}$ & $\begin{array}{c}0.005 \\
(0.23)\end{array}$ \\
\hline Home Ownership & $\begin{array}{l}0.46 * * * \\
(9.34)\end{array}$ & $\begin{array}{l}0.44 * * * \\
(8.80)\end{array}$ & $\begin{array}{l}0.50 * * * \\
(7.32)\end{array}$ & $\begin{array}{l}0.35 * * * \\
(4.77)\end{array}$ \\
\hline CCP member & $\begin{array}{l}0.48 * * * \\
(6.19)\end{array}$ & $\begin{array}{l}0.59 * * * \\
(7.41)\end{array}$ & $\begin{array}{l}1.09 * * * \\
(6.48)\end{array}$ & $\begin{array}{l}0.47 * * * \\
(4.97)\end{array}$ \\
\hline North China & $\begin{array}{l}0.30 * * \\
(3.43)\end{array}$ & $\begin{array}{l}0.32 * * * \\
(3.64)\end{array}$ & $\begin{array}{l}0.40 * * \\
(3.11)\end{array}$ & $\begin{array}{c}0.14 \\
(1.17)\end{array}$ \\
\hline Northeast China & $\begin{array}{c}-0.15 \\
(1.89)\end{array}$ & $\begin{array}{c}-0.18 * \\
(2.23)\end{array}$ & $\begin{array}{l}0.46 * * * \\
(4.13)\end{array}$ & $\begin{array}{l}-1.00 * * * \\
(7.52)\end{array}$ \\
\hline East China & $\begin{array}{c}0.14 * \\
(2.03)\end{array}$ & $\begin{array}{c}0.16 * \\
(2.30)\end{array}$ & $\begin{array}{c}0.18 * \\
(2.03) \\
\end{array}$ & $\begin{array}{c}0.03 \\
(0.32)\end{array}$ \\
\hline Southwest China & $\begin{array}{l}0.28 * * \\
(3.48)\end{array}$ & $\begin{array}{l}0.28 * * \\
(3.47)\end{array}$ & $\begin{array}{l}0.29 * * \\
(2.89)\end{array}$ & $\begin{array}{c}0.25 \\
(1.84)\end{array}$ \\
\hline Northwest China & $\begin{array}{c}-0.19 \\
(1.88)\end{array}$ & $\begin{array}{c}-0.14 \\
(1.39)\end{array}$ & $\begin{array}{c}0.07 \\
(0.60)\end{array}$ & $\begin{array}{c}-0.69 * * \\
(3.37)\end{array}$ \\
\hline Constant & $\begin{array}{l}-2.42 * * * \\
(10.02)\end{array}$ & $\begin{array}{l}-3.34 * * * \\
(12.58)\end{array}$ & $\begin{array}{l}-2.80 * * * \\
(7.52)\end{array}$ & $\begin{array}{l}-3.23 * * * \\
(7.73)\end{array}$ \\
\hline
\end{tabular}

Notes: For Model 1 and $2 \mathrm{~N}=8,073$, for Model $3 \mathrm{~N}=4,376$ and Model $4 \mathrm{~N}=3,697 .{ }^{* * *}=p<.001,{ }^{* *}=p<.01,{ }^{*}=p<.05$. 
Table 6. Democratic values and the level of education. Source: China General Social Survey 2013.

\begin{tabular}{lcccrr}
\hline \multicolumn{1}{c}{ Education Level } \\
\hline Democratic Values & No Education & Elementary & Middle & High & College \\
\hline Low & $0 \%$ & $0 \%$ & $1 \%$ & $2 \%$ & $3 \%$ \\
Medium Low & $4 \%$ & $6 \%$ & $7 \%$ & $11 \%$ & $17 \%$ \\
Medium High & $18 \%$ & $19 \%$ & $25 \%$ & $29 \%$ & $34 \%$ \\
High & $78 \%$ & $75 \%$ & $100 \%$ & $100 \%$ & $100 \%$ \\
\hline Total & $100 \%$ & $(1,976)$ & $(2,745)$ & $(1,848)$ & $(1,625)$ \\
(freq) & $(1,021)$ & & & &
\end{tabular}

Table 7. Factors that influence individual democratic values in China (2013) for respondents over 20 years old.

\begin{tabular}{|c|c|c|c|}
\hline Variables & Model 1 & Model 2 (Rural) & Model 3 (Urban) \\
\hline Voting in Local Elections & $\begin{array}{l}0.27 * * * \\
(5.53)\end{array}$ & $\begin{array}{c}0.17 * \\
(2.39)\end{array}$ & $\begin{array}{l}0.37 * * * \\
(5.30)\end{array}$ \\
\hline Generational Differences & $\begin{array}{l}0.31 * * * \\
(5.86)\end{array}$ & $\begin{array}{l}0.44 * * * \\
(5.79)\end{array}$ & $\begin{array}{c}0.17 * \\
(2.26)\end{array}$ \\
\hline Education & $\begin{array}{l}-0.20 * * * \\
(7.96)\end{array}$ & $\begin{array}{l}-0.17 * * * \\
(4.59)\end{array}$ & $\begin{array}{l}-0.23 * * * \\
(6.74)\end{array}$ \\
\hline Gender & $\begin{array}{l}-0.17 * * \\
(3.48)\end{array}$ & $\begin{array}{c}-0.13 \\
(1.68)\end{array}$ & $\begin{array}{l}-0.20 * * \\
(3.03)\end{array}$ \\
\hline Class Status & $\begin{array}{c}-0.03 \\
(1.92)\end{array}$ & $\begin{array}{c}-0.04 \\
(1.66)\end{array}$ & $\begin{array}{c}-0.02 \\
(0.94)\end{array}$ \\
\hline Home Ownership & $\begin{array}{c}0.06 \\
(1.29)\end{array}$ & $\begin{array}{c}0.06 \\
(0.82)\end{array}$ & $\begin{array}{c}0.06 \\
(0.83)\end{array}$ \\
\hline Rural & $\begin{array}{l}0.41 * * * \\
(7.27)\end{array}$ & & \\
\hline CCP member & $\begin{array}{c}-0.07 \\
(0.88)\end{array}$ & $\begin{array}{c}-0.18 \\
(1.25)\end{array}$ & $\begin{array}{c}-0.008 \\
(0.09)\end{array}$ \\
\hline North China & $\begin{array}{r}-0.01 \\
(0.17)\end{array}$ & $\begin{array}{c}-0.11 \\
(0.86)\end{array}$ & $\begin{array}{c}0.09 \\
(0.92)\end{array}$ \\
\hline Northeast China & $\begin{array}{l}0.57 * * * \\
(6.66)\end{array}$ & $\begin{array}{l}0.48 * * * \\
(3.81)\end{array}$ & $\begin{array}{l}0.71 * * * \\
(5.98)\end{array}$ \\
\hline East China & $\begin{array}{l}0.18 * * \\
(2.69)\end{array}$ & $\begin{array}{c}0.09 \\
(0.99)\end{array}$ & $\begin{array}{l}0.29 * * \\
(3.02)\end{array}$ \\
\hline Southwest China & $\begin{array}{l}0.25 * * \\
(2.94)\end{array}$ & $\begin{array}{c}0.15 \\
(1.35)\end{array}$ & $\begin{array}{l}0.41 * * \\
(3.04)\end{array}$ \\
\hline Northwest China & $\begin{array}{l}0.27 * * \\
(2.60)\end{array}$ & $\begin{array}{c}0.33 * \\
(2.48)\end{array}$ & $\begin{array}{c}0.14 \\
(0.83)\end{array}$ \\
\hline
\end{tabular}

Notes: For Model $1 \mathrm{~N}=8,239$, for Model $2 \mathrm{~N}=4,386$ and Model $3 \mathrm{~N}=3,853 .{ }^{* * *}=p<.001,{ }^{* *}=p<.01,{ }^{*}=p<.05$. 